DOI 10.37882/2223-2982.2020.09.13

\title{
НАНТСКИЙ ЭДИКТ И «ГОСУДАРСТВО В ГОСУДАРСТВЕ» ГУГЕНОТОВ
}

\section{THE EDICT OF NANTES AND THE "STATE WITHIN A STATE" OF THE HUGUENOTS \\ D. Evgrashin}

Summary: The article is devoted to the problem of consolidating the autonomy of the Huguenots in the famous Nantes Edict. Using the historical genetic method and the principle of historicism, we comprehend the main acquisitions and privileges of Protestants. The basic points of view in domestic and foreign historiography on a specific issue are considered. In conclusion, it is concluded that the autonomy granted by the Nantes Edict to the Huguenots was insufficient to create a «state in a state.»

Keywords: Henry IV; Edict of Nantes; Huguenots; wars of religion; La Rochelle; Edict Beaulieu.

\author{
Евграшин Дмитрий Алексеевич \\ аспирант, ассистент, Самарский национальный \\ исследовательский университет \\ имени академика С.П. Королёва \\ sindead@gmail.com
}

Аннотация: Статья посвящена проблеме закрепления автономии гугенотов в знаменитом Нантском эдикте. Используя историко-генетический метод и принцип историзма, разбираются основные приобретения и привилегии протестантов. Рассматриваются основные точки зрения в отечественной и зарубежной историографии по данному вопросу. В заключении делается вывод о том, что автономия, дарованная гугенотам по Нантскому эдикту, не создала «государства в государстве».

Ключевые слова: Генрих IV; Нантский эдикт; гугеноты; религиозные войны; Ла Рошель; Эдикт Болье.

дит для ретроспективного обзора, но что мог сделать Генрих четвертый в реалиях 1598 года?

Как бывший лидер гугенотов он не мог оставить своих бывших подопечных без каких-либо преференций или наград. С другой стороны, большая часть его окружения на момент 1598 года стала уже католической. При нем остались только лишь самые верные его сподвижники-протестанты главным, из которых конечно же стал герцог Сюлли, другие прежние его соратники такие как Филипп Дюплесси-Морнэ [2, Р. 206] и Агриппа д'Обинье [3, С. 183], удалились со двора еще в 1594 году, когда Генрих принял католицизм.

Таким образом, люди, бывшие некогда при дворе в свите короля Наварры, теперь представляли для него некую угрозу, так как их авторитет среди гугенотов был непререкаем, особенно это касается Дюплесси-Морнэ, которого называли папой гугенотов. С другой стороны, опираться на протестантов он не мог, потому что численность гугенотов во Франции на тот момент даже по самым оптимистичным цифрам не превышала 10 процентов от населения государства.

Если же рассмотреть интересы католиков, то Генрих как католический монарх сразу после принятия «истинной веры» в 1594 году начал даровать земли и права городам и дворянам-католикам, которые так или иначе участвовали в движении Лиги. Очевидно, что он делал это для того, чтобы переманить их на свою сторону, нужно отметить, что его тактика оказалась единственно вер- 
ной, и в кратчайшие сроки самые видные деятели Лиги перешли на сторону нового короля Франции, тем самым выбив почву из-под ног Филиппа II.

Но уже тогда в 1594 м году многие лидеры гугенотов были явно не в восторге от многочисленных дарований католикам. Они считали себя победителями, ведь именно их кандидат стал королём, и естественно ожидали от него больших преференций. Примеры этому мы можем увидеть в воспоминаниях Дюплесси-Морнэ (хотя он и понимал, что Генрих не мог сохранить свой протестантизм). Поэтому первому Бурбону на французском троне необходимо было сделать если не дар, то широкий жест своим бывшим соратникам и дать им уже упомянутые 200 крепостей по всей территории Франции, крупнейшей из которых являлась Ла-Рошель.

Так называемые «секретные» [1, С. 193] постановления не таили в себе ничего зловещего. Они представляли собой прилагаемый перечень исключений и дополнительных положений, в которых предпринималась попытка согласовать общие статьи Нантского эдикта с конкретными обещаниями, данными отдельным городам Лиги, таким как Париж или Тулуза, когда они сдались на милость короля: им гарантировалась свобода от принудительных гугенотских служб в городских пределах и пригородах. Некоторые секретные постановления также касались создания протестантских университетов во Франции и подготовки священников. Эти положения были бы уместны и в составе общих статей, поскольку разделение между ними не всегда было чётким. Однако наиболее значимыми уступками в процессе умиротворения были письма. В них Генрих IV предоставил протестантам ограниченную независимость в плане военного и политического статуса. Предполагалось, что за выплаты священникам несёт ответственность сам король. Содержание гарнизонов предоставлялось на ограниченный период в восемь лет с момента даты публикации указа в парламенте Парижа, но при этом войска предписывалось размещать в соответствии с королевскими указаниями, а командиры назначались королём. Однако формулировка допускала, что при назначении будут учтены пожелания протестантов.

Письма воспринимались как личные обещания короля протестантам, а не официальные акты. Их подтвердят в 1611 году, но затем в 1629 году Людовик XIII отречётся от них в Але, и тогда гугеноты потеряют одно из основных преимуществ, предоставленных Нантским эдиктом.

На основании этих писем многие исследователи утверждают, что Нантский эдикт создал «государство в государстве». Этот тезис нам представляется не совсем точным. Оплачивая содержание церквей и гарнизонов, король купил приверженность со стороны протестантов, как и в случае с Лигой, и приблизил их к короне, а не оттолкнул окончательно. Основные статьи Эдикта (пункт 82) [1, С. 192] строго запрещали протестантские политические собрания на национальном или региональном уровне, поэтому «Объединённые провинции Миди» были официально распущены. Статья 43 из числа секретных постановлений, однако, разрешала беседы и провинциальные синоды, но исключительно в религиозных целях и в присутствии королевского судьи. Протестантам отвели отдельные палаты в парламентах для специфичных случаев, но при этом там применялся королевский закон. Королевские католические судьи присутствовали всегда. Протестанты должны были платить десятину и уважать католические празднества. [1, С. 193] Гугенотам по-прежнему не разрешалось коллективно владеть школами, больницами, церквями и консисториями. Признавалась только частная собственность отдельного человека. По сути, смысл эдикта - не крайняя степень независимости, позволяющая кальвинистам жить по собственным законам, а степень зависимости, которая бы устраивала короля и гугенотов, сохраняя их лояльность друг другу. Можно сказать, что создавалось не «государство в государстве», а одно государство с двумя системами. По сравнению со скромными свободами, предоставленными гугенотам в религиозной сфере, крупные денежные выплаты, компенсации и освобождения от налогообложения, предоставленные городам Католической лиги, не говоря уже о праве исповедовать католическую веру, исключая любые другие, позволяют считать «государством в государстве» скорее их, а не протестантов. Самое большее, этот указ сделал гугенотов сословием королевства в королевстве - одной из многочисленных групп населения, защищенных определёнными привилегиями. В некоторых отношениях поддержка, оказываемая образовательным учреждениям протестантов, оказалась наиболее значимым долгосрочным ключом к выживанию сословия. Однако, по сравнению с другими - аристократией, дворянством мантии и духовенством - гугеноты оставались маргинальной группой традиционного французского общества и в условиях, отличных от тех, которые преобладали во времена правления Генриха IV, могли стать ещё уязвимее.

Тем не менее за двенадцать лет правления после издания эдикта Генрих не столкнулся с какими-то проблемами в отношении гугенотов. Только после его смерти во время регентства его жены Марии Медичи. Протестанты показали свои головы и начали активно оппонировать действующей власти, что и привело к столкновениям между ними и кардиналом Ришелье.

Должен ли был Генрих VI предвидеть это в 1598 году? Мы считаем, что нет. Конечно с юридической точки зрения именно Нантский эдикт позволил гугенотам содержать несколько сотен крепостей, но на протяжении всей второй половины XVI века гугенотs и так имели огромный военный контингент на юге и на юго-востоке Фран- 
ции и никакие юридические документы не были нужны протестантам для ведения открытых военных кампаний против королевских войск. Здесь можно вспомнить войну Трех Генрихов в 1588 году, когда войска протестантов во главе с Генрихом Бурбоном наголову разбили короля Генриха III и Генриха Гиза. Более того, еще раньше в первой половине восьмидесятых годов XVI века гугеноты беспрепятственно наняли более 30 тысяч наемников из германских протестантских княжеств, которые составляли основную часть армии Генриха Наваррского вплоть до 1589 года.

Таким образом, даже отсутствие юридического документа или юридической возможности содержать крепости, гарнизоны и военные контингенты на территории Франции не помешали бы гугенотам в случае ужесточения внутриполитической и религиозной борьбы во Франции снова заявить о себе как о серьезной военной силе, которая сможет с оружием в руках продвигать свою религию и свои интересы с оружием в руках.

С другой стороны, Генриху удалось именно с помощью этого юридического акта локализовать и держать под контролем протестантскую оппозицию имея возможность в случае новой эскалации конфликта легально подавить выступления гугенотов если такие будут иметь место. В реальности же никаких восстаний не последовало, и Бурбон больше не имел внутренних проблем с протестантами.

Не стоит также забывать и об ограничениях, которые закреплялись за протестантами, самым главным, из которых, стало ограничение на публичное исправление своей религии. В связи с чем, гугенотам стало намного сложнее заниматься пропагандой своих религиозных убеждений и как следствие численность протестантов во Франции находилась под контролем государственной власти.

\section{ЛИТЕРАТУРА}

1. Ардашев П.Н. Хрестоматия по всеобщей истории. Новая история в отрывках из источников, Ч. 1. Эпоха гуманизма и реформации. Киев, 1914.

2. A Huguenot family in the XVI century: the memoirs of Philippe du Mornay, Soeur du Plessis Marly. Nabu Press, 2011.

3. Обинье Т.А. Приключения барона де Фенеста. Жизнь, рассказанная его детям. Москва. 2001.

4. Люблинская А.Д. Французский абсолютизм в первой трети XVII века. М.-Л. 1965.

5. Greengrass M. France in the Age of Henri IV: The Struggle for Stability. Routledge. 2013.

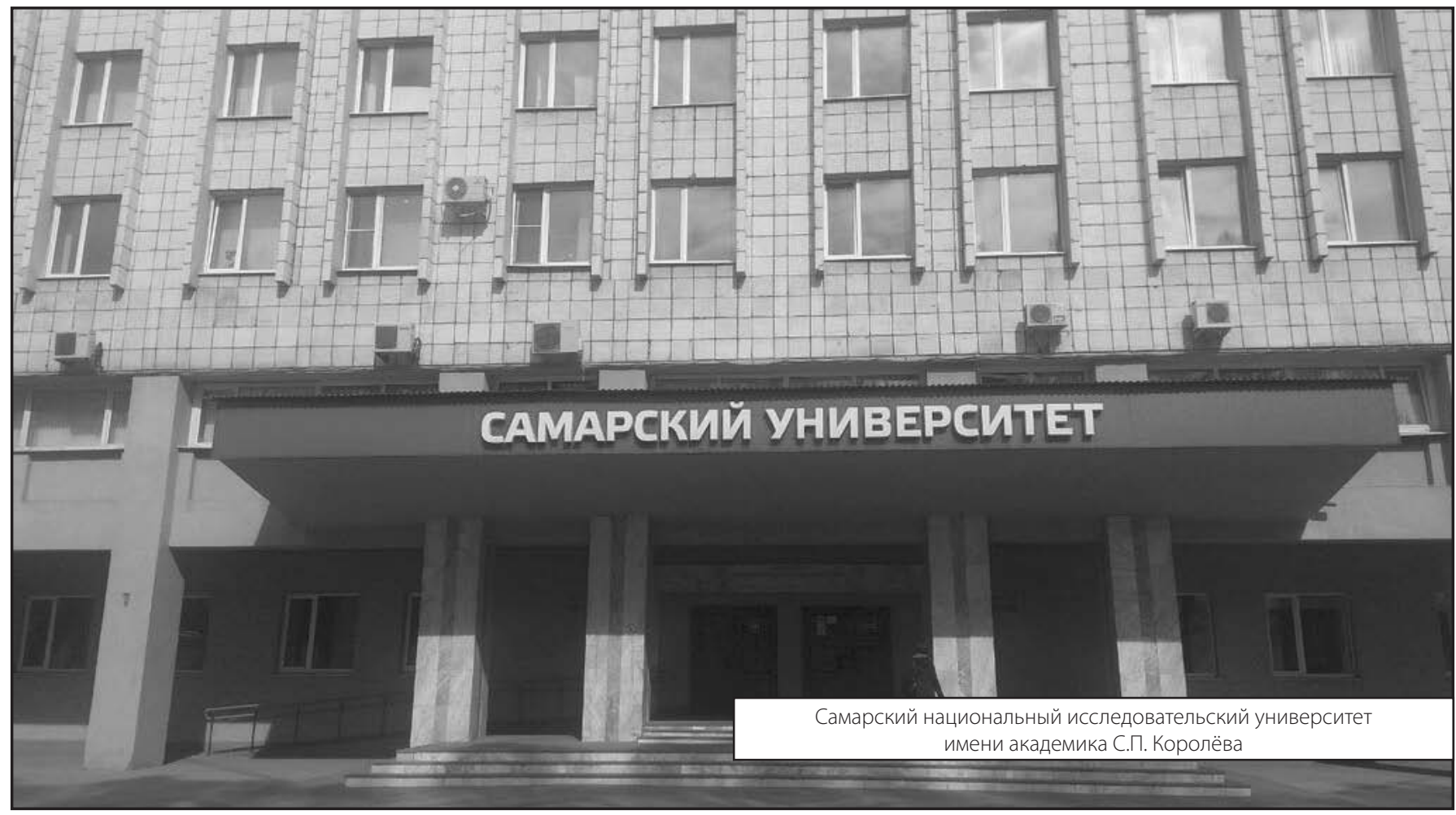

